\title{
Application of the Energy Service Contract to Improve Energy Efficiency in Use of Resources in the Housing and Utility Complex
}

\author{
Svetlana Shilkina* \\ Moscow State University of Civil Engineering, Yaroslavskoe shosse, 26, Moscow, 129337, Russia
}

\begin{abstract}
The need for development of new efficient technologies in the modern world arises from growth in resource consumption. One of the main consumers of fuel and energy resources in Russia is a housing and utility complex. More than half of the buildings in the country were built more than 40 years ago. Despite the fact that the buildings, for the most part, have not yet their service life expired, the systems that provide electricity, heat and water to housing and utility services are in an unsatisfactory condition, they are morally outdated and do not meet modern needs. In recent decades, many developments that bring significant savings in resources appeared, both by reducing losses during their transportation, and by introducing technologies that optimize using of the resources. Implementation of such projects, although it brings tangible savings in resources, requires significant financial investments. Households and large municipalities often do not have an opportunity to find such significant money at a time. A solution to this problem can be involvement of an energy service company, which at its own expense implements a project to improve the energy efficiency of using resources, and then, within several years, it will receive some income for cost of saved resources. The article examines one of such projects, presents possible ways of implementing energy service activities, and presents the results of financial and economic calculations of consequences of a potential investor's participation in such a project. As a result of implementation of the energy service project, electricity consumption will decrease by $15 \%$, the saved funds will allow the investor to have the return on investment from participation in the project in the amount of more than $25 \%$ per annum, and the customer will significantly improve reliability and quality of providing the population with electricity. Results of the research conducted by the author demonstrate a great potential of practice of implementing energy service contracts for solving priority tasks of increasing the energy efficiency of the housing and utility complex.
\end{abstract}

* Corresponding author: Shilkina@bk.ru 


\section{Introduction}

Most of the energy consumed in the world is wasted during its transmission and inefficient use technologies; as a result, huge funds are lost, which is an important problem today, as it leads to a significant increase in costs, and exacerbates pollution of the planet with carbon dioxide emitted when generating energy. Now, energy efficiency is one of the simplest and most cost-effective ways to cope with the climate change, with the air pollution we breathe, as this method allows us to reduce production costs, and, as a result, increase labour productivity and well-being of the people. Despite the fact that energy efficiency and energy saving have the same goal: to reduce energy consumption, they are different concepts that do not imply the same thing. Energy saving is based on reducing the use of energy-consuming processes, e.g., the population uses less air conditioners and heaters, more often turns off lighting devices and technical lighting, and uses water sparingly. Moreover, energy efficiency is use of the technology that helps to avoid or reduce energy waste. Although, in principle, both of these concepts can be considered in the same context, since they are based on the desire of the world community to use energy more wisely [1].

\section{Global Situation Analysis}

Analysis of statistical information demonstrates that the world economy has a tendency to decrease its energy intensity for recent decades, e. g., since 1990, the gross domestic product (GDP) has more than doubled, and total energy consumption has increased by less than $60 \%[2,3,4]$.

The energy intensity of a national economy is often used as an indicator of energy efficiency due to availability of the initial data for calculation. This indicator takes into account the energy required to meet demand for the national energy services. However, a country with relatively low energy intensity may have no high energy-efficiency. For example, a small service-oriented country with a mild climate may have lower energy intensity than a large industrialized country with a cold climate, even if it uses energy more efficiently. In addition, activities to reduce energy intensity will not necessarily be driven by efficiency gains. To obtain reliable results, it is necessary to carry out a comprehensive analysis taking into account many factors that include the following: economy structure (share of large energy-consuming industries); geographic characteristics (e. g. longer distances implying higher demand for transport services); general climatic conditions (demand for space heating and cooling) and many other factors that determine trends in the final energy consumption. Let us look at statistics. According to the data of the International Energy Agency (IEA) [2, 3, 4], the final consumption of energy resources by sectors of the economy of the OECD member countries as of 2018 is distributed in percentage as follows. 


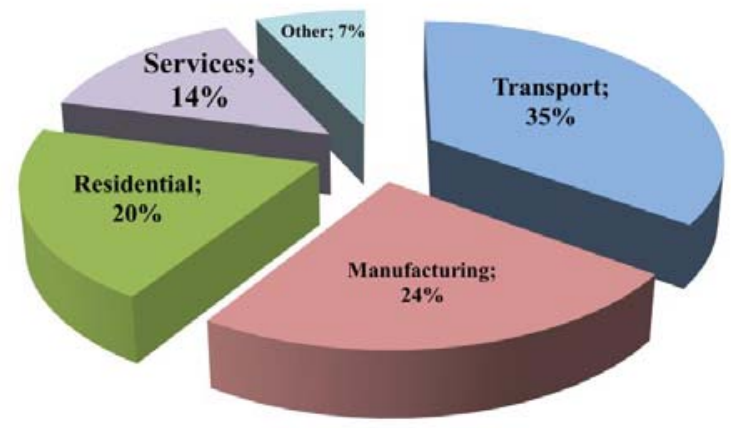

Fig. 1. Consumption of fuel and energy resources by economic sector in member countries of the Organization for Economic Development and Cooperation, 2018.

Passenger cars alone consume more energy than the entire residential sector and, together with trucks, account for almost a third of the final energy $\mathrm{CO}_{2}$ emissions (Figure. 2) $[2,3,4]$. The position of transport as the leading driver of total energy consumption is influenced by the fact that, in the United States, as well as in Canada and Australia, transport is the largest consumption sector, in large part due to long distances per inhabitant and use of larger vehicles.

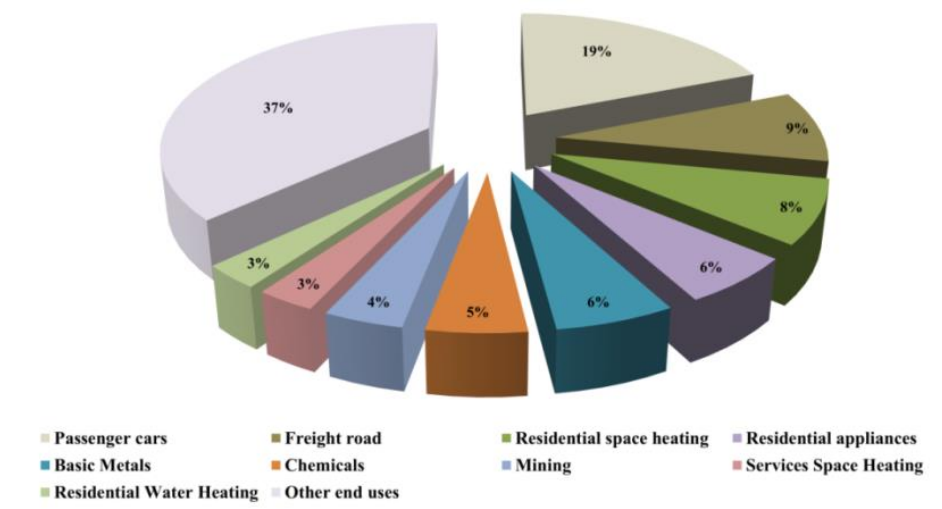

Fig. 2. $\mathrm{CO}_{2}$ emission sources in the context of energy consumption.

Let us take a good look at the construction sector and the housing and utility complex. The construction industry is critical to the economy and life of people in any country. For example, in the United States, construction of commercial and residential buildings accounts for approximately $6.5 \%$ of the gross domestic product (GDP) [1]. Building requirements change over time to meet the needs of society, including changes in design and construction methods, materials and interior design concepts. Today, in all developed countries, more and more attention is paid to the role of buildings in energy consumption, as well as in the environmental consequences arising during using residential and commercial buildings [5]. In addition, in modern conditions, more and more homeowners are faced with the need to minimize the cost of purchased resources and current activities when providing high-quality utilities. Attention is also paid to ecology, environmental awareness is more and more rising, understanding of the need to preserve natural resources such as clean air, water, energy and land by people is growing. In this regard, in recent 
decades, the concept of the energy efficient building and its further development-Smart City [5] is becoming increasingly popular.

Having the energy efficient building is increasingly vital, as energy consumption becomes a critical economic problem due to high demand [6]. Therefore, all households should assess how well energy resources are used for house heating, cooling and lighting. The operation of energy-efficient buildings offers cost savings, reducing greenhouse gas emissions. For many years, the OECD member countries have been conducting research on energy efficiency of residential and non-residential assets $[2,3,4]$. According to the IEA, space heating in the residential sector accounts for more than half of energy consumption in the developed countries (Figure 3). Naturally, the range of indicators is very large, depending on regions and climatic conditions. Thus, the largest share falls on the European countries (73\% in Belgium and $72 \%$ in Hungary) and, as a rule, the lowest share falls on Asia and Oceania (Japan-26\% and New Zealand-30\%).

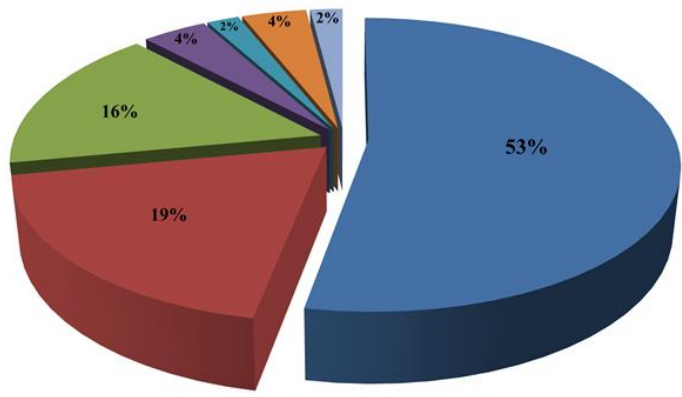

\begin{tabular}{|c|c|}
\hline - Space heating & " Residential appliances $\|$ Water heating \\
\hline $\begin{array}{l}\text { Space cooling } \\
\text { Nonspecified }\end{array}$ & = Lighting \\
\hline
\end{tabular}

Fig. 3. Average structure of energy consumption in residential premises in the OECD countries.

According to the IEA, improvements in space heating energy efficiency have been introduced in all the OECD countries in the 21 st century, mainly due to improvements in building insulation, renovation of old buildings and improvements in heating equipment [2, $3,4]$. The effects are visible in trends in the intensity of heating of residential premises, defined as energy consumption per unit of floor area, which has significantly decreased in most of the IEA countries (Figure 4.). For example, Finland, France, Germany and Korea have declined more than $30 \%$ since 2000 . 


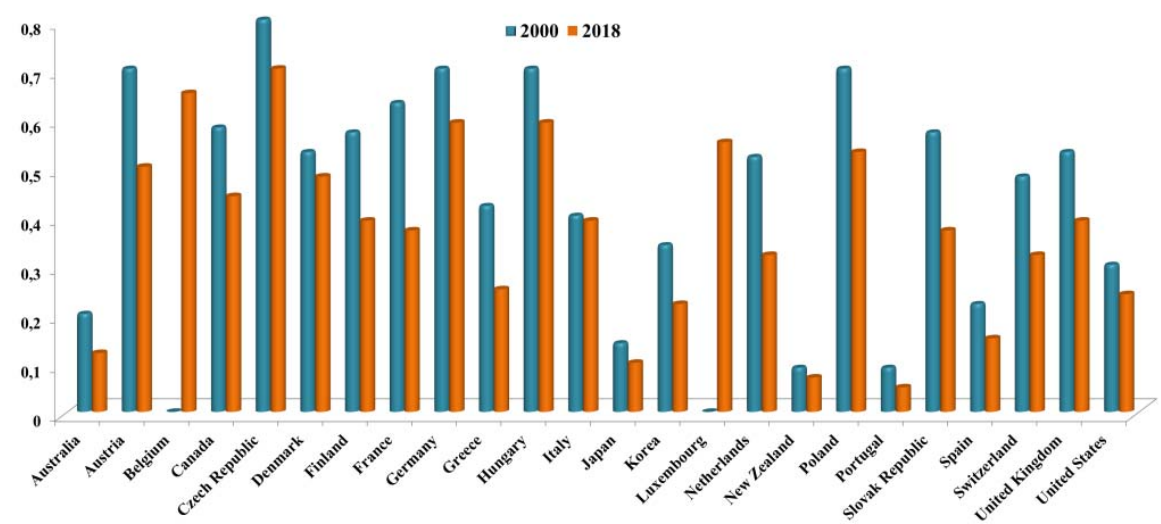

Fig. 4. Energy consumption per unit of floor area in the OECD member states in 2000 and 2018, $\mathrm{GJ} / \mathrm{m}^{2}$.

Warmer countries tend to have a lower heating rate because, on average, less energy is required to keep the room temperature at a comfortable level [6].

\section{Analysis of Situation in Russia}

Data on consumption of fuel and energy resources in Russia per sectors of the economy for 2015-2018 demonstrate that the largest volume of consumption of fuel and energy resources, namely $83 \%$ of the total, falls on 4 sectors: electricity and heat, manufacturing, transport, as well as the sector of buildings and housing and public utilities [7].

With a $1.3 \%$ growth of the GDP, there was a decrease in consumption of fuel and energy resources (FER) by more than $6.6 \mathrm{mln}$ tons of oil equivalent (toe) in the Russian Federation in 2019. This led to the fact that the GDP energy intensity indicator in 2019 demonstrated the minimum value in five years - 9.6 toe $/ \mathrm{mln}$ rubles in 2016 prices. This decline is not due to technological factors in all industries. Moreover, dynamics of fuel and energy resources consumption is very different in different industries. Thus, consumption of fuel and energy resources in housing and utility services is reduced by $5.16 \mathrm{mln}$ toe due to a warmer average monthly temperature compared to previous years. At the same time, extension of service life for heat supply of low-efficiency boiler houses led to increase in fuel and energy consumption by $1.5 \mathrm{mln}$ toe. In addition, the mining industry demonstrated a significant increase in fuel and energy resources consumption by $7.5 \mathrm{mln}$ toe. It should be noted that implementation of a complex of activities to improve energy efficiency played a significant role in reducing the energy intensity of the Russian economy. The activities were implemented at the level of the state and sectors. This is especially noticeable while generating electricity, when energy-efficient equipment was actively introduced, and a complex of activities was implemented to optimize balances of electricity and heat production. Thanks to this, about $80 \%$ of the total savings of the fuel and energy resources in the electricity sector was gained. The same impact was exerted by introduction of new technologies to reduce use of fuel and energy resources in budget institutions and in the service sector. If we analyse parameters of energy efficiency in the context of regions, then energy intensity of regional economies sometimes differs by 10-15 times, e.g. in Lipetsk region, the energy intensity is 55.3 toe/mln rubles, and 3.7 toe/mln rubles in Moscow $[8,9]$.

Many regions are actively developing programs in the energy efficiency and energy saving. As a result, the total amount of their financing in 2019 amounted to more than 136 billion rubles, which is 1.6 times more than in 2018. At the same time, in six regions, 
activities to improve energy efficiency and energy saving were not even planned, and in another ten regions funds for their implementation were not allocated. However, regions often do not use the full range of energy efficiency and energy saving opportunities. Thus, use of one of the most promising options for implementing energy efficiency improvements - conclusion of energy service contracts in Russia decreased by $13 \%$ in 2019 compared to 2018. And use of the energy service contracts for implementation of the energy-saving activities in the apartment buildings was used only in Moscow, the total cost of which for three years (2017-2019) amounted to more than 4 billion rubles [8,9].

\section{Methods}

In August 2016, the Analytical Centre of the Government of the Russian Federation issued the Recommended Practice for Calculating Effects from Implementation of Activities to Save Energy and Increase Energy Efficiency (hereinafter the "Recommended Practice").

The document details classification and characteristics of energy saving activities, provides methods for assessing and calculating energy effects from implementation of energy saving and energy efficiency activities, and recommends a simplified method of financial and economic assessment of investments in the energy saving activities. The costs of energy supply to industry and the housing and utility complex mainly depend on the amount of the energy generated by power plants per unit of time and duration of their operation. Therefore, reduction in power parameters and/or operating time will have a positive effect on energy savings [10,11].

Figure 5 clearly illustrates energy savings in connection with modernization of energyconsuming systems, which is reflected in reduction in the power consumption of power plants and their operating time.

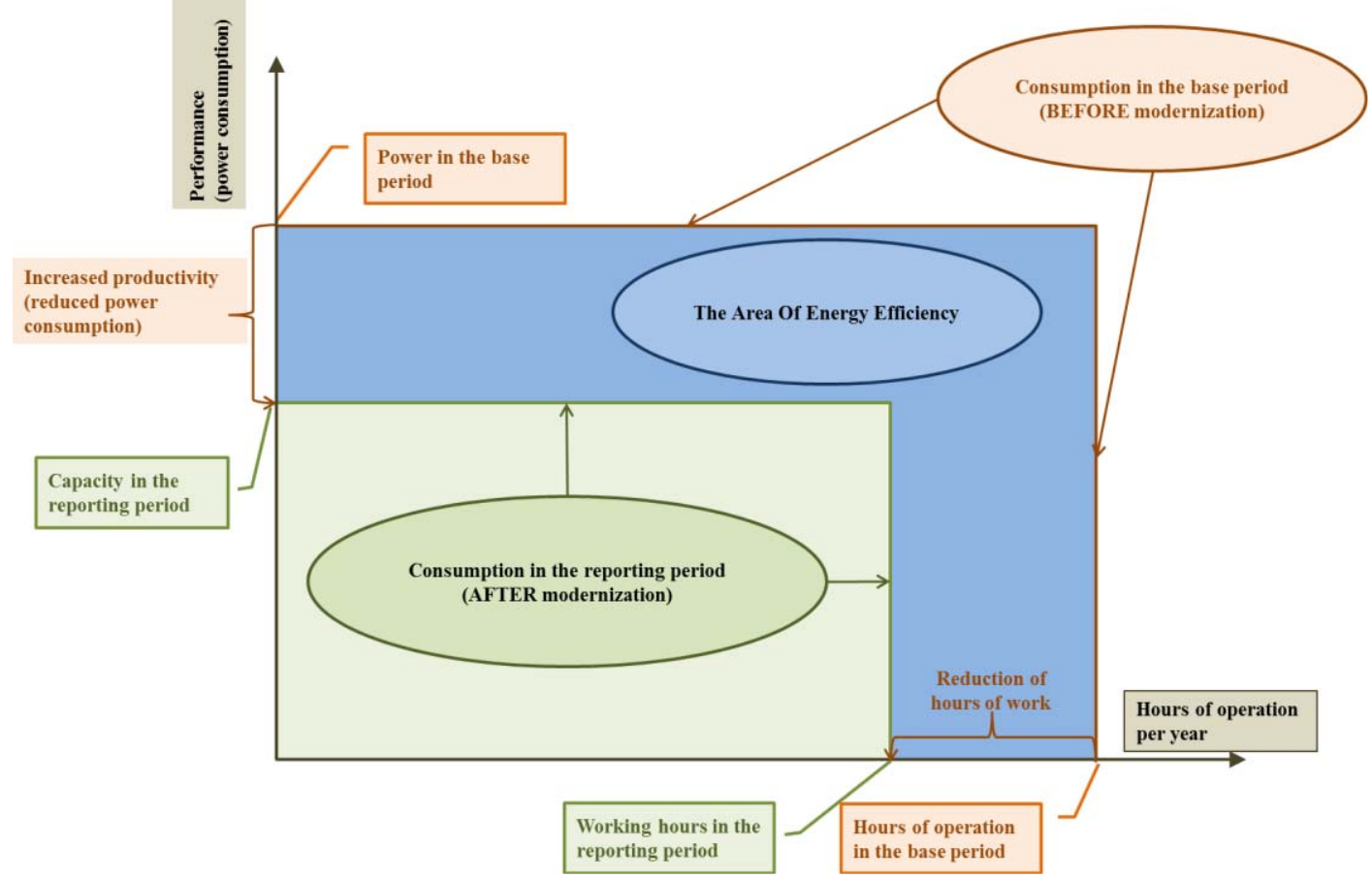

Fig. 5. Energy saving scheme in connection with modernization of energy-consuming systems. 
According to the Recommended Practice, when calculating an energy effect from implementation of activities to improve energy efficiency, several methods can be used:

- Analog method: analysing the results of implementation of similar projects and activities at other facilities. This method is the most widely used due to its simplicity. However, it is very inaccurate, since it does not take into account all the specifics of a particular project.

- Calculation method: using balance procedures, specific indicators and/or other physical laws. This method is usually used by professionals when it is necessary to calculate the main parameters of projects and select a set of activities for implementation of these projects

- According to measuring techniques, the method is mainly used by professionals, contractors when concluding energy service contracts: project customers and energy service companies. This is due to the fact that energy service contracts are very long (3-10 years) and usually require significant capital investments, therefore, an accurate calculation of energy savings is a key parameter in making decisions about concluding such an agreement.

At the same time, the third method - conclusion of an energy service contract-is one of the main directions for implementation of complex projects and energy efficiency activities. Energy service contract is a contract that involves a specialized energy service company that performs a full range of work on implementation of energy-saving technologies at the customer's company. As a rule, the customer makes payment after completion of the project from the funds saved due to introduction of energy-saving technologies of the lighting system, but analogously it is possible to determine the energy savings resulted from optimization of the building heating system and other energyconsuming systems that operate for a long time throughout a year $[10,11]$.

In this article, the author proposes to consider effectiveness of the energy service contract on a specific example of its implementation.

Based on the results of the survey of the power supply system of an urban settlement in the Krasnoyarsk Territory, which was conducted to determine possible areas of energy savings, increase energy efficiency and assess of the energy-saving potential, a decision was taken to consider the issue of concluding an Agreement on providing the energy services. Based on the results of the survey and preliminary calculations, the main problem areas in the power supply of the urban settlement were identified. Based on the analysis of the data collected from the Automatic system for commercial accounting of power consumption for the year [12...18] on consumption of active and reactive energy by the settlement, it was determined that $\cos \varphi$ ranges from 0.63 to 0.91 . Therefore, there is a significant potential for increasing the power factor to 1 .

To bring all the parameters of quality of electrical energy to GOST 32144-2013, it was proposed to use the Software and Hardware Complex (SHC) built according to the principles of FACTS-devices.

The Software and Hardware Complex includes the following core components:

1. Software.

2. Components of the system of commercial and engineering metering of electricity.

3. System of sensors with an option for collecting data from other sections of the system, equipment, without restrictions on the types of sensors, protocol and transmission channel.

4. Automated process control system (APCS).

5. SCADA system.

6. Complex of FACTS devices.

7. Associated equipment that is required for functioning of the Software and Hardware Complex, such as controllers, optical current and voltage transformers, etc. 
It is this approach and such a number of subsystems that allow the Customer to save several times the money in comparison with the costs for solving these problems individually, and achieve the following results:

- reduce consumption of active energy from 15 to $36 \%$ in the "hubs";

- reduce practically to zero consumption of reactive power from the system;

- bring all the parameters of finite element to GOST 32144-2013;

- reduce the number of shutdowns and accidents;

- extend the service life of electrical equipment from $25 \%$;

- improve the quality of life in the community;

- reduce the process time for release of the finished product for industrial companies in the settlement, which, in turn, allows to reduce cost of finished products and increase volume of its output; and

- reduce capital costs for construction of a company's power supply system up to 10 times.

Based on the data received, the Customer developed Terms of Reference (TOR) for implementation of a complex of activities for resource savings.

The Terms of Reference defines the following:

- goals and objectives of resource savings;

- basic data on the settlement, structure of the housing stock and industrial sector;

- list of objects for which resource-saving services should be implemented;

- main directions of increasing energy and economic efficiency;

- planned resource-saving activities; and

- basic requirements for resource-saving services.

In addition, one of the main requirements was determined as the Contractor's obligation to develop and agree with the Customer a Procedure and an algorithm for calculating the economic effect to determine the amount and timing of taking the remuneration by the Contractor after implementation of the activities under the energy service contract $[19 . .24]$. The following data of Table 1 are taken as the initial data for calculating results from implementation of the energy service contract:

Table 1. Initial data.

\begin{tabular}{|c|c|c|c|c|c|c|c|}
\hline \multirow{2}{*}{ Parameter } & \multirow{2}{*}{$\begin{array}{c}\text { Unit of } \\
\text { measureme } \\
\text { nt }\end{array}$} & \multicolumn{5}{|c|}{ Year } & \multirow{2}{*}{ Total } \\
\hline & & 2021 & 2022 & 2023 & $\ldots$ & 2028 & \\
\hline $\begin{array}{l}\text { Electricity } \\
\text { consumption } \\
\text { without } \\
\text { energy } \\
\text { service } \\
\text { project }\end{array}$ & $\begin{array}{l}\text { thousand } \\
\text { kWh per } \\
\text { year }\end{array}$ & 600000 & 600000 & 600000 & $\ldots$ & 600000 & 4800000 \\
\hline $\begin{array}{l}\text { Projected } \\
\text { rise in } \\
\text { electricity } \\
\text { prices }\end{array}$ & $\%$ & 100,0 & 102,4 & 102,4 & $\ldots$ & 101,5 & \\
\hline $\begin{array}{l}\text { Electricity } \\
\text { cost based on } \\
\text { the forecast }\end{array}$ & $\mathrm{rub} / \mathrm{kWh}$ & 4,00 & 4,10 & 4,19 & $\ldots$ & 4,74 & \\
\hline $\begin{array}{l}\text { Electricity } \\
\text { costs }\end{array}$ & $\begin{array}{l}\text { thousand } \\
\text { rubles }\end{array}$ & $\begin{array}{c}2400 \\
000\end{array}$ & $\begin{array}{c}2457 \\
474\end{array}$ & $\begin{array}{c}2516 \\
475\end{array}$ & $\cdots$ & 2845390 & $\begin{array}{c}20940 \\
796\end{array}$ \\
\hline
\end{tabular}




\section{Survey}

Calculations demonstrated that implementation of the energy service project resulted to decrease of electricity consumption by $15 \%$. According to agreement between Customer and Investor, all savings from the reduction in amount of payment for electricity, which appeared as a result of resource savings, is the Investor's income for six years. In exchange, the Investor, using its own financial and engineering resources, provides implementation of the energy service activities, including development and implementation of the software and hardware system, as well as system management during the period of the energy service contract. The energy service contract prepared includes provisions for connecting new consumers, options for calculating the Contractor's remuneration in case of deviation of decrease in electricity consumption both upward and downward, changes in cost of electricity that differ from the projected cost, as well as other provisions, taking into account that term of the contract, including the construction stage, is more than seven years. Table 2 demonstrates basic agreements.

Table 2. Baseline scenario calculation.

\begin{tabular}{|c|c|c|c|c|c|c|c|}
\hline & & & 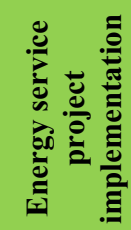 & & & & \\
\hline \multirow[b]{2}{*}{ Parameter } & \multirow{2}{*}{$\begin{array}{c}\text { Unit of } \\
\text { measurement }\end{array}$} & \multicolumn{5}{|c|}{ Year } & \multirow[b]{2}{*}{ Total } \\
\hline & & 2021 & 2022 & 2023 & $\ldots$ & 2028 & \\
\hline $\begin{array}{l}\text { Electricity } \\
\text { consumption } \\
\text { after } \\
\text { implementation } \\
\text { of the energy } \\
\text { service project }\end{array}$ & $\begin{array}{c}\text { thousand } \\
\text { kWh per } \\
\text { year }\end{array}$ & 600000 & 600000 & $\begin{array}{l}510 \\
000\end{array}$ & 510000 & 510000 & $\begin{array}{c}4260 \\
000\end{array}$ \\
\hline Energy saving & $\begin{array}{c}\text { thousand } \\
\text { kWh per } \\
\text { year } \\
\end{array}$ & & & 90000 & 90000 & 90000 & 540000 \\
\hline $\begin{array}{l}\text { ectricity cost } \\
\text { after } \\
\text { implementation } \\
\text { of the energy } \\
\text { service project }\end{array}$ & $\begin{array}{l}\text { thousand } \\
\text { rubles }\end{array}$ & $\begin{array}{c}2400 \\
000\end{array}$ & $\begin{array}{c}2457 \\
474\end{array}$ & $\begin{array}{c}2139 \\
003\end{array}$ & $\cdots$ & $\begin{array}{c}2418 \\
582\end{array}$ & $\begin{array}{c}18528 \\
298\end{array}$ \\
\hline $\begin{array}{l}\text { Economic } \\
\text { effect from } \\
\text { implementation } \\
\text { of the activities }\end{array}$ & $\begin{array}{l}\text { thousand } \\
\text { rubles }\end{array}$ & $\mathbf{0}$ & 0 & $\begin{array}{l}377 \\
471\end{array}$ & $\cdots$ & 426809 & $\begin{array}{c}2412 \\
498\end{array}$ \\
\hline
\end{tabular}

Naturally, when agreeing on the terms of the energy service contract, the Investor developed a feasibility study for energy service activities, which, in addition to calculating of specification of the equipment used, included a financial and economic model for implementation of this project. 
The calculations were carried out in a wide range of possible changes in the main parameters that affect the economic efficiency of the project. For example, Table 3 demonstrates aggregated and rounded results of calculations for a base case scenario.

Table 3. Parameters of the energy service project for the investor, basic version

\begin{tabular}{|c|c|c|c|c|c|c|c|c|}
\hline \multirow{2}{*}{ Parameter } & \multirow{2}{*}{$\begin{array}{c}\text { Unit of } \\
\text { measurement }\end{array}$} & \multicolumn{6}{|c|}{ Year } & \multirow{2}{*}{ Total } \\
\hline & & 2022 & 2023 & 2024 & 2025 & $\ldots$ & 2028 & \\
\hline Investments & $\begin{array}{l}\text { thousand } \\
\text { rubles }\end{array}$ & $\begin{array}{l}(800 \\
000)\end{array}$ & & & & $\cdots$ & & \\
\hline Cash flow & $\begin{array}{l}\text { thousand } \\
\text { rubles }\end{array}$ & $\begin{array}{l}(800 \\
000) \\
\end{array}$ & 377471 & 386371 & $\begin{array}{l}395 \\
925\end{array}$ & $\cdots$ & 426809 & $\begin{array}{c}1612 \\
498 \\
\end{array}$ \\
\hline $\begin{array}{l}\text { Cumulative } \\
\text { cash flow }\end{array}$ & $\begin{array}{l}\text { thousand } \\
\text { rubles }\end{array}$ & $\begin{array}{l}(800 \\
000)\end{array}$ & $(422$ 529) & (36 158) & $\begin{array}{l}359 \\
767\end{array}$ & $\cdots$ & 1612498 & \\
\hline $\begin{array}{l}\text { Simple } \\
\text { payback } \\
\text { period } \\
\end{array}$ & years & & & & 3,09 & $\cdots$ & & \\
\hline $\begin{array}{l}\text { Discounted } \\
\text { cash flow }\end{array}$ & $\begin{array}{l}\text { thousand } \\
\text { rubles }\end{array}$ & $\begin{array}{l}(800 \\
000)\end{array}$ & 328236 & 292152 & $\begin{array}{l}260 \\
327\end{array}$ & $\ldots$ & 184521 & \\
\hline $\begin{array}{l}\text { Cumulative } \\
\text { discounted } \\
\text { cash flow }\end{array}$ & $\begin{array}{l}\text { thousand } \\
\text { rubles }\end{array}$ & $\begin{array}{l}(800 \\
000)\end{array}$ & (471 764) & (179 613) & $\begin{array}{c}80 \\
615\end{array}$ & $\cdots$ & 705774 & \\
\hline $\begin{array}{l}\text { Discounted } \\
\text { payback } \\
\text { period }\end{array}$ & years & & & & 3,69 & $\ldots$ & & \\
\hline
\end{tabular}

Table 4. Parameters of the energy service project for the investor, basic version 1

\begin{tabular}{|l|c|c|}
\hline Parameter & Unit of measurement & Meaning \\
\hline Equity cost & $\%$ & $15 \%$ \\
\hline IRR (for investor) & $\%$ & $28,38 \%$ \\
\hline NPV (for investor) & thousand rubles & 705774 \\
\hline Simple payback period & years & 3,1 \\
\hline Discounted payback period (for an investor) & years & 3,7 \\
\hline
\end{tabular}

\section{Calculation results}

To minimize risks, the Investor performed a sensitivity analysis based on impact of the changes in the main parameters on the final results. The results obtained confirmed for the Investor that implementation of this energy service contract is economically justified. 


\section{Discussion}

There is a huge unimplemented potential for energy saving in the housing stock, this sphere of life is one of the most energy-intensive [14]. The long-term dynamics of increasing energy efficiency in the housing stock allows not only saving money for the population, but can also significantly improve the quality of life of the community, reduce cost of primary hydrocarbons and reduce emissions of both pollutants and greenhouse gases into the atmosphere [15]. The need to solve this problem has already been recognized at the top level. As a confirmation, we can cite Petr Bobylev, Director of Department of Competition, Energy Efficiency and Environment of the Ministry of Economic Development of Russia: "We need to take into account that most of the housing in our country is apartment buildings built in the $60-80$ s of the last century. Therefore, we are faced with a task of not just building new housing with high energy-efficiency classes, but also increasing the energy efficiency of existing housing. "The Ministry of Economic Development of Russia has developed and submitted to the government a draft resolution providing for inclusion in regional programs to improve energy efficiency and regional programs for energy efficient capital repairs. Currently, the problems of eliminating barriers for implementation of energy service contracts in the housing stock are being worked out [16].

\section{Summary}

The studies presented in the article make it possible to state that use of the practice of implementing energy service contracts in housing and utility services has a great potential for solving the priority tasks of the housing stock. It should be kept in mind that the subject of energy-efficient activities could be reduction of almost any resource consumed by both population and industrial enterprises: electric and thermal energy, water supply and wastewater disposal.

\section{References}

1. U.S. Department of Energy, https://www.energy.gov/science-innovation/energyefficiency

2. Statistics report Energy Efficiency Indicators Highlights 2020 edition, International Energy Agency, www.iea.org

3. Energy Efficiency 2019, International Energy Agency, www.iea.org

4. Energy Efficiency 2020, International Energy Agency, www.iea.org

5. M. Tobias, Energy Efficiency in Civil Engineering and Architecture Energy Efficiency in Engineering, New York Engineers, March 8, (2019), https://www.nyengineers.com/blog/energy-efficiency-in-civil-engineering-and-architecture

6. J. Hanania, J. Jenden, K. Stenhouse, J. Donev, Energy efficient building design, University of Calgary, https://energyeducation.ca/encyclopedia/Energy_efficient_building_design

7. A comprehensive plan of measures to improve the energy efficiency of the economy of the Russian Federation, Order of the Government of the Russian Federation" On Approval of the Comprehensive Plan of measures to improve the Energy Efficiency of the Economy of the Russian Federation " of April 19, 2018, № 703-p.(2018)

8. State report on the state of energy saving and energy efficiency improvement in the Russian Federation in 2019, Moscow-Ministry of Economic Development of the Russian Federation (Ministry of Economic Development of the Russian Federation) 2020, 117 p.(2020)

9. State report on the state of energy saving and energy efficiency improvement in the Russian Federation in 2017, Moscow-Ministry of Economic Development of the 
Russian Federation (Ministry of Economic Development of the Russian Federation) 2018, 263 p.(2018)

10. Methodological recommendations for calculating the effects of implementing measures to save energy and improve energy efficiency, Under the general editorship of Gasho E. G. Analytical Center under the Government of the Russian Federation / Reference and analytical Document, 2016, 56 p.(2016)

11. Methodological recommendations for assessing the effectiveness of the implementation of measures to save energy and improve energy efficiency in industry, Ministry of Economic Development of Russia, 14 p.(2019)

12. M. Zhang, Y. Zhan, S. He, Power Quality Data Compression Based on Iterative PCA Algorithm in Smart Distribution Systems. Smart Grid and Renewable Energy, 8, 366378p. doi: 10.4236/sgre.2017.812024.(2017)

13. E. V. Timofeev, Improving energy efficiency in agriculture / E. V. Timofeev, A. F. Erk, V. N. Sudachenko, V. A. Razmuk. - Text : direct / / Young scientist. — 2017. — № 4 (138). — pp. 213-217. (2017) — URL: https://moluch.ru/archive/138/38851/.

14. Assessment of additional power losses from reducing the quality of electrical energy in the elements of power supply systems / S. Yu. Dolinger [et al.] / / Omsk Scientific Bulletin. Ser. Devices, machines, and technologies. - 2013. - № 2(120). - pp. 178183.(2013)

15. I.V. Zhezhelenko, Yu.L. Saenko, A.V. Gorpinich, Influence of electric energy quality on decrease in service life and reduction of reliability of electric equipment. // Electrician, № 3, 2008, pp. 15-21.(2008)

16. I. Fardiev, Y. Shelochkov, B. Zabelkin, V. Meer, Management reactive power - an efficient facility of increasing to reliability and economy of the working the power system. // Energy of The Republic Of Tatarstan. № 4 (8), 2007, pp. 18-25.(2007)

17. M. S. Balabanov, G. S. Balabanov, M. B. Oshchepkov, Reactive power compensation devices in networks with autonomous power sources. Magazine "Turbines and Diesels" / September-October 2012, pp. 64-67.(2012)

18. V.P. Zakaryukin, A.V. Kryukov, Mathematical models of loading of the electrical power systems, constructed on the basis of phase coordinates, monograph, Publishing house: Irkutsk State University of Communications, 2013, 176 p.(2013)

19. I. A. Mutugullina, Advantages of the energy service contract Journal: Proceedings of Higher educational Institutions, Energy Problems Volume: 19, Issue: 1-2, Year: 2017, pp. 174-178. (2017)

20. T. V. Shaposhnikova, Advantages and risks of energy service contracts, Young scientist, № 6 (2016), pp. 969-972.

21. R. R. Nogovitsyn, S. N. Kladkina, Features of the implementation of energy service contracts in the field of energy saving in the housing and utilities sector (on the example of the Republic of Sakha (Yakutia)), Journal of Problems of Modern Economics 3(67), pp. 196-199(2018)

22. S. V. Guzhov, Methods for determining and confirming the energy-saving effect in heat and power supply systems: monograph / S. V. Guzhov. - M.: Publishing House of the Power Engineering Institute, Moscow, (2015), 112 p.

23. L. E. Nazarova, Analyzing practical experience of energy service contracts in Russia, Journal Digest Finance, 2017, vol 22, iss 1, pp. 59-61(2017)

24. S. V. Ratner, L. E. Nazarova, Evaluation of efficiency and analysis of barriers to the implementation of regional energy saving programs / / Russian Journal of Management, 2016, Vol. 4, №. 2, pp. 152-162(2016) 